\title{
ANALISIS KEBIASAAN MAKAN PADA IBU HAMIL KEKURANGAN ENERGI KRONIK DI WILAYAH KERJA PUSKESMAS PULUBALA KABUPATEN GORONTALO
}

\author{
Analysis of Dietary Pattern on Pregnant Mother's with Chronic \\ Energy Defisiency (CED) in Health Centre \\ Of Pulubala Gorontalo District
}

\author{
'Zuriati Muhamad, ${ }^{2}$ Hermawati Hamalding, ${ }^{3}$ Haslina Ahmad \\ 1) Fakultas IImu Kesehatan Universitas Muhammadiyah Gorontalo \\ 2) Fakultas Kesehatan Masyarakat Universitas Indonesia Timur Makassar \\ 3) Sekolat Tinggi IImu Kesehatan Yapika Makassar
}

zuriati.muhamad@umgo.ac.id

\begin{abstract}
ABSTRAK
Kurang Energi Kronis (KEK) merupakan salah satu masalah kurang gizi yang sering terjadi pada wanita hamil, yang disebabkan oleh kekurangan energi dalam jangka waktu yang cukup lama. Penelitian ini menganalisis kebiasaan makan penyebab KEK pada ibu hamil di wilayah kerja Puskesmas Pulubala tahun 2017. Penelitian ini menggunakan pendekatan kualitatif, melalui wawancara mendalam dan observasi dikediaman ibu hamil. Informan utama dalam penelitian ini adalah ibu hamil yang menderita Kekurangan Energi Kronis (KEK) dengan penentuan ukuran Lingkar Lengan Atas (LILA). Aspek kebiasaan makan merupakan salah satu penyebab KEK pada ibu hamil, semua aspek perilaku kebiasaan makan seperti tidak makan bersama keluarga, pola makanan yang kurang beragam dan bersumber energi, frekuensi dan porsi makanan yang kurang, pantangan terhadap makana yang memang baik untuk dikonsumsi, cara mendistribusikan makanan keluarga yang kurang baik, dan cara memilih bahan makanan yang kurang baik merupakan penyebab terjadinya KEK pada ibu hamil.
\end{abstract}

Kata Kunci : Kebiasaan makan, KEK, Ibu hamil

\section{ABSTRACT}

Chronic Energy Deficiensy (CED) is one of the most common malnutrition problems in pregnant women, caused by shortage of energy over long periods of time.This study analyzed the eating habits of CED causes in pregnant women in Pulubala health centre 2017. This study used a qualitative approach, through in-depth interviews and observations in the abode of pregnant women. The main informants in this study were pregnant women who suffer from Chronic Energy Deficiency (CED) with the determination of the size of the Upper Arm Circumference (LILA). Aspects of eating habits is one of the causes of CED in pregnant women, all aspects of eating habits such as not eating with family, less diverse and energy-sourced diet patterns, the frequency and portion of food is lacking, abstinence against eating that is good for consumption, how to distribute poor family food, and how to choose less good food is the cause of CED in pregnant women.

Keywords: Eating Habits, CED, pregnant women 


\section{PENDAHULUAN}

Pada hakekatnya dalam mewujudkan kesejahteraan rakyat adalah dengan meningkatkan kualitas manusia. Gizi yang baik merupakan salah satu faktor yang diperlukan untuk menghasilkan manusia yang berkualitas. Upaya meningkatkan SDM seharusnya dimulai sedini mungkin sejak janin dalam kandungan. Bila keadaan kesehatan dan status gizi ibu hamil baik, maka besar peluang janin yang dikandungnya akan baik dan keselamatan ibu sewaktu melahirkan akan terjamin (Mawaddah dan Hardinsyah, 2008). Sesuai dengan yang diungkapkan Kartikasari et al (2011), bahwa status gizi ibu sebelum dan selama hamil dapat mempengaruhi pertumbuhan janin yang sedang dikandung. Bila status gizi ibu normal pada masa sebelum dan selama hamil kemungkinan besar akan melahirkan bayi yang sehat, cukup bulan dengan berat badan normal. Dengan kata lain, kualitas bayi yang dilahirkansangat bergantung pada keadaan gizi ibu sebelum dan selama hamil.

Hasil penelitian lain menunjukkan bahwa (KEK) pada batas LILA $23,5 \mathrm{~cm}$ belum merupakan resiko untuk melahirkan Barat Badan Lahir Rendah (BBLR). Sedangkan ibu hamil dengan Kurang Energi Kronis (KEK) pada batas LILA kurang $23 \mathrm{~cm}$ mempunyai resiko 2 kali untuk melahirkan BBLR dibandingkan dengan ibu yang mempunyai Lingkar Lengan Atas (LILA) lebih dari $23 \mathrm{~cm}$. Adapun dampak dari KEK pada ibu hamil meliputi abortus (keguguran) dan kematian janin. Sedangkan untuk dampak jangka panjang bisa menyebabkan terhambatnya pertumbuhan janin, kecacatan pada janin, dan BBLR (berat bayi lahir rendah).

Berdasarkan penelitian Rosmeri (2000) dalam Waryana, (2010) menunjukkan bahwa ibu yang memiliki status gizi kurang (kurus) sejak sebelum hamil mempunyai resiko lebih tinggi lagi, yaitu 4,27 kali untuk melahirkan bayi BBLR dibandingkan dengan ibu yang mempunyai status gizi baik. Ada beberapa faktor yang mempengaruhi pola makan pada ibu hamil KEK, yaitu pengetahuan dan sikap ibu hamil KEK itu sendiri. Pengetahuan dan sikap berhubungan dengan kebiasaan ibu hamil. Kekurangan gizi bisa terjadi akibat ketidaktahuan seseorang dalam mengakses pangannya, atau memilih makanan yang kurang atau tidak bergizi karena ketidaktahuannya. Ibu hamil yang memiliki pengetahuan tentang pola makan yang baik untuk dikonsumsi akan menerapkannya pada kehidupannya sehari-hari dimana hal tersebut menjadi kebiasaanya untuk mengatur pola makan.

Organisasi Kesehatan Dunia (WHO) melaporkan bahwa prevalensi anemia dan Kekurangan Energi Kronis (KEK) pada kehamilan secara global 35 sampai 75\% dimana secara bermakna tinggi pada trimester ketiga dibandingkan dengan trimester pertama dan kedua kehamilan. WHO juga mencatat $40 \%$ kematian ibu di negara berkembang berkaitan dengan anemia dan KEK dengan prevalensi terbanyak dari kasus tersebut karena ibu KEK yang dapat menyebabkan status gizinya Berkurang.

Menurut Survei Demografi dan Kesehatan Indonesia (SDKI) 2007, Angka Kematian Ibu (AKI) sebesar 228 per 100.000 kelahiranhidup (Depkes, 2010) angka ini meningkat pada tahun 2012 yaitu sebesar 359 per 100.000 kelahiran hidup (Depkes dalam Gunawan, 2013). Di Provinsi Gorontalo berdasarkan data Profil Kesehatan Provinsi Gorontalo tahun 2015, prevalensi ibu hamil KEK sebesar 3.253orang, angka ini meningkatdibandingkan tahun 2014 sebesar 2.963 (Dinkes, 2016). Kabupaten Gorontalo merupakan salah satu Kabupaten yang ada di Provinsi Gorontalo. Berdasarkan profilgizi Kabupaten Gorontalo tahun 2015, prevalensi ibu hamil KEK sebesar 1.035 ibu hamil (Dinkes, 2012). Di Kecamatan Pulubala pada tahun 2016 ada102 bumil KEK. 
Berdasarkan data awal yang peneliti dapatkan melalui data rekam medik Puskesmas Pulubala, ibu hamilyang sering berkunjung ke Puskesmas Pulubala sejumlah 73 orang. Berdasarkan observasi dan hasil wawancara dari 10 ibu hamil yang mengalami KEK, didapatkan bahwa beberapa orang tidak mengkonsumsi makanan yang mengandung protein. Selain itu ibu hamil KEK mengaku bahwa sebagian dari mereka kurang nafsu makan sehingga asupan makanan yang bergizi untuk ibu hamil kurang dikonsumsi sehingga mengakibatkan KEK. Selain nafsu makan, terhambat pola makan oleh kebiasaan dan budaya dari masing-masing lingkungan ibu hamil yang mengalami KEK.

Berdasarkan uraian diatas peneliti tertarik untuk melakukan penelitian ini dengan judul analisis kebiasaan makan ibu hamil KEK di wilayah Kerja Puskesmas Pulubala Kabupaten Gorontalo.

\section{METODE PENELITIAN}

Penelitian dilaksanakan di wilayah kerja Puskesmas Pulubala pada bulan marettahun 2017 dengan metode penelitian kualitatif. Teknik pengambilan sampel dalam penelitian ini adalah snowball sampling yaitu teknik pengambilan sampel informan, yang pada awalnya jumlahnya sedikit, lama-lama menjadi besar.

\section{PEMBAHASAN}

Tabel 1 karakteristik responden berdasarkan usia

\begin{tabular}{|c|c|c|c|}
\hline \multicolumn{2}{|c|}{$\begin{array}{l}\text { KARAKTERISTIK } \\
\text { RESPONDEN }\end{array}$} & $\mathrm{n}$ & $\%$ \\
\hline \multirow[t]{2}{*}{ Usia } & $<20$ tahun & 4 & 20 \\
\hline & $\begin{array}{c}\text { 20-35 tahun } \\
>35 \text { tahun }\end{array}$ & $\begin{array}{l}6 \\
0\end{array}$ & $\begin{array}{c}60 \\
0\end{array}$ \\
\hline \multirow[t]{2}{*}{$\begin{array}{l}\text { Riwayat } \\
\text { kehamilan } \\
\text { dan } \\
\text { persalinan }\end{array}$} & $\begin{array}{c}\text { Gestasi } \\
\text { (kehamilan) } \\
\text { / P (partus) } \\
\text { Primi }\end{array}$ & 7 & 70 \\
\hline & $\begin{array}{c}\text { Multi } \\
\text { Grandemulti } \\
\text { A (abortus) }\end{array}$ & $\begin{array}{l}3 \\
0 \\
0\end{array}$ & 30 \\
\hline $\begin{array}{l}\text { Riwayat } \\
\text { penyakit }\end{array}$ & $\begin{array}{l}\text { Tidak ada } \\
\text { riwayat } \\
\text { penyakit }\end{array}$ & 10 & 100 \\
\hline
\end{tabular}

Sumber : Olahan data primer(2017)

Berdasarkan hasil penelitian bahwa ibu hamil KEK yang paling banyak adalah ibu hamil yang primi gravidarum yaitu 7 informan (70\%) dan yang paling sedikit yaitu multi gravidarum sebanyak 3 informan (3\%). Berdasarkan hasil penelitian bahwa rata-rata ibu hamil tidak memiliki riwayat penyakit. 
Tabel 2. Jenis Makanan

\begin{tabular}{|c|c|c|}
\hline $\begin{array}{l}\text { Kelompok } \\
\text { Makanan }\end{array}$ & $\begin{array}{l}\text { Nama } \\
\text { sampel }\end{array}$ & Analisa data \\
\hline 1. Karbohidrat & $\begin{array}{l}\text { Ny. SA, SM, } \\
\text { MY, YG, SL, } \\
\text { NK, AL, MM, } \\
\text { OA, dan MM }\end{array}$ & $\begin{array}{l}\text { Hasil penelitian } 10 \text { informan ibu hamil KEK } \\
\text { rata-rata mengkonsumsi karbohidrat baik itu } \\
\text { nasi putih ataupun pengganti nasi yang } \\
\text { mengandung karbohidrat. Tetapi dalam } \\
\text { jumlah sedikit dan tidak sering. Seperti yang } \\
\text { dikemukakan informan Ny. S.A "saya } \\
\text { makan pagi nasi". }\end{array}$ \\
\hline $\begin{array}{l}\text { 2. Sayur- } \\
\text { sayuran }\end{array}$ & $\begin{array}{l}\text { NY. MY, YG, } \\
\text { SL, NK, AL, } \\
\text { MM, OA,dan } \\
\text { MM. }\end{array}$ & $\begin{array}{l}\text { Hasil penelitian } 10 \text { informan ibu hamil KEK } \\
\text { ada } 8 \text { informan yang mengkonsumsi } \\
\text { sayuran. Adapun dalam mengkonsumsi } \\
\text { sayuran tersebut informan mengaku jarang } \\
\text { mengkonsumsi tergantung hasil dari kebun. } \\
\text { Seperti yang dikemukakan oleh Ny. O.A } \\
\text { "saya ini ses kalau makan sayor hanya } \\
\text { kacang panjang trus karna itu yang ada d } \\
\text { kobong milu jadi tidak trus-trus makan, } \\
\text { kalaupun makan bayam nanti orang sablah } \\
\text { rumah ada kase soalnya pa depe kebun } \\
\text { banyak". }\end{array}$ \\
\hline 3. Buah-buahan & $\begin{array}{l}\text { Ny. SA, SM, } \\
\text { MY, YG, SL, } \\
\text { NK, AL, MM, } \\
\text { OA, dan MM }\end{array}$ & $\begin{array}{l}\text { Hasil penelitian } 10 \text { informan ibu hamil KEK } \\
\text { rata-rata mengkonsumsi buah walaupun } \\
\text { hanya kadang dan sesuai dengan buah apa } \\
\text { yang ada dilingkungan mereka. Seperti } \\
\text { yang dikemukakan oleh Ny. M.Y "kalau ses } \\
\text { buah itu saya jaga mkan tapi tidak salalu } \\
\text { karna nanti saya punya paitua bawa kamari } \\
\text { dari kobong juga ses". }\end{array}$ \\
\hline 4. Susu & $\begin{array}{l}\text { Ny. SA, SM, } \\
\text { MY, YG, dan } \\
\text { SL. }\end{array}$ & $\begin{array}{l}\text { Hasil penelitian } 10 \text { informan hanya ada } 5 \\
\text { informan yang mengkonsumsi susu secara } \\
\text { rutin, sedangan yang tidak mengkonsumsi } \\
\text { susu mengakui mereka malas dan tidak } \\
\text { mampu untuk membeli susu. Seperti yang } \\
\text { di kemukakan oleh Ny. S.L } \\
\text { "soalnya tidak dapa susu gratis dari puskes } \\
\text { ses" }\end{array}$ \\
\hline 5. Tablet Fe & $\begin{array}{l}\text { Ny. SA, SM, } \\
\text { MY, YG, SL, } \\
\text { NK, AL, MM, } \\
\text { OA, dan MM. }\end{array}$ & $\begin{array}{l}\text { Hasil penelitian } 10 \text { informan mendapatkan } \\
\text { tablet Fe dari puskesmas adapun rata-rata } \\
\text { dari } 10 \text { informan tersebut jarang } \\
\text { mengkonsumsi dengan alasan lupa dan } \\
\text { malas. Seperti yang di ungkapkan oleh Ny. } \\
\text { M.M } \\
\text { "tidak biasa minum obat ses" }\end{array}$ \\
\hline
\end{tabular}

Sumber : Olahan data primer (2017)

Tabel 3. Frekuensi 


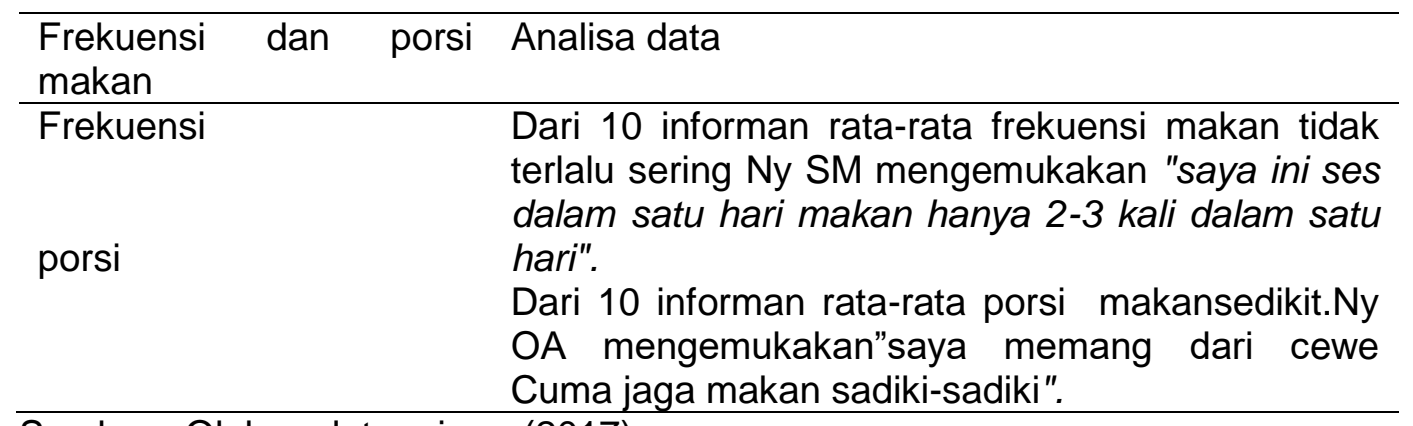

Sumber : Olahan data primer (2017)

Tabel 4. Pantangan makanan

\begin{tabular}{ll}
\hline Pantangan makanan & Analisa data \\
\hline Tidak ada pantangan & Dari 10 informan ada 3 informan mengatakan ada \\
dalam mkanan ibu hamil & pantangan dalam makan seperti buah nenas Ny \\
& OA, SM, MY mengemukakan "Ti hulango marah \\
& mo makan nenas muda deng nenas masa".
\end{tabular}

Tabel 5. informan kunci

Informan kunci

Petugas Kesehatan Dari hasil di atas bahwa petugas kesehatan (BIKOR, Bidan desa, Petugas gizi), mengemukakan bahwa semua makanan bisa dikonsumsi yang penting bergizi dan bersih dan tidak ada pantangan makanan bagi ibu hamil. Dibawah ini pernyataan bidan koordinator :

1. Pendapat petugas kesehatan tentang kebiasaan makan ibu selama hamil?

"Dalam hal makan ibu hamil seharusnya mengkonsumsi makanan yang bergizi, porsi kecil tapi sering dan tidak ada pantangan dalam makanan".Adapun kebiasaan ibu hamil disini yaitu makan-makanan yang berkarbohidrat tinggi.

2. Makanan apa saja yang di konsumsi oleh ibu selama hamil ?

"makanan yang biasanya di konsumsi ibu-ibu hamil yaitu makanan yang berasal dari hasil kebun sendiri misalnya kacang hijau, jagung, papaya, kangkung dan masih banyak lagi"

3. Selain makanan, apa saja yang di konsumsi oleh ibu selama hamil ?

"kami sebagai petugas kesehatan selalu mengingatkan ibu hamil untuk mengkonsumsi susu ibu hamil, biskuit ibu hamil, tablet FE dengan rutin.

4. Berapa kali makan selama ibu hamil dalam 1 hari ? "banyak ibu hamil yang mengeluhkanbahwa nafsu makan mereka lebih menurun saat kehamilan muda sehingga membuat berat badan ibu semakin menurun dan berat badan semakin menurun dari biasanya sehari 2-3 kali sekarang 2-1 kali sehari"

5. Apa ada pantangan makan bagi ibu hamil kek ? 


\begin{tabular}{ll}
\hline & "tidak ada makanan pantangan bagi ibu hamil" \\
6. Upaya-upaya petugas kesehatan \\
"adapun upaya-upaya yang kami lakukan yaitu \\
membuat kelas ibu hamil di setiap posyandu kemudian \\
mengontrol berat badan ibu hamil, pemeriksaan lila \\
setiap posyandu, pemberian tablet FE, susu ibu hamil \\
dan biskuit ibu hamil" \\
\hline keluarga masih belum mengerti tentang makanan apa \\
saja yang bisa dikonsumsi oleh ibu, dan sebagian kecil \\
masih mepercayai bahwa ada pantangan makanan \\
bagi ibu hamil. \\
Pernyataan menurut keluarga Ny. OA,MY, YG, SL, NK, \\
AL, MM. \\
"saya pe anak cuma suka makan bubur tiap pagi, depe \\
makan Cuma 2 sampe 3 kali tiap hari ses, tidak mau \\
mo minum susu lagi, saya jaga mara dia bo tidak mo ba \\
dengar ses" \\
Kader masih belum mengerti tentang makananapa saja \\
yang bisa dikonsumsi oleh ibu, dan sebagian kecil \\
masih mepercayai bahwa ada pantangan makanan \\
bagi ibu hamil. Pernyataan menurut kader Ny. N, EA, IL \\
"Ibu-ibu hamil yang kurus ini tidak mo badengar kalo \\
saya mo suru makan-makan kasana yang banya ses, \\
ada olo yang kurus memang so dari cewe ses jadi pas \\
ada mangidam so tatamba kurus" \\
\hline Kader
\end{tabular}

Sumber : Olahan data primer (2017)

\section{Pola Makanan yang dimakan}

Selama masa kehamilan, sangat dibutuhkan asupan bahan makanan yang bernilai gizi tinggi dan diperlukan dalam menjada kesehatan dan meningkatkan kecerdasan janin. Oleh karena itu, agar ibu dan janin tetap mendapat asupan gizi, berikut beberapa saran yang bisa dilakukan (Emilia, 2012).

a) Jangan biarkan perut kosong.

b) Pilih makanan yang hangat- hangat karena bisa membuat lambung yang terasa perih seperti terelaksasi.

c) Saat bangun pagi, jika belum nafsu makan, maka makanlah biscuit dan teh hangat. Namun begitu, ibu harus tetap mencoba sarapan.

d) Bila ibu sering merasa kembung, hindari makanan yang dapat memicu kembung antara lain kacang tanah yang biasa berada didalam bumbu kacang.

e) Batasi masakan bersantan, ketan, nangka, sayur nangka, sayur asem, buah - buahan yang asam atau dapat mengiritasi lambung.

f) Penting untuk menghindari rokok, cuka, kopi, juga narkoba karena akan membahayakan ibu maupun janin.

g) Umumnya ibu hamil membutuhkan lebih banyak darah, untuk itu ibu hamil diharuskan mengonsumsi makanan yang banyak mengandung zat besi, seperti sayuran hijau tua, tempe, tahu, kacang hijau, kacang merah, dan kacang-kacangan lainya, telur, ikan, daging. Jangan lupa minum obat penambah darah sesuai anjuran dokter .

h) Penting pula bagi ibu hamil untu makan buah-buahan segar seperti jeruk, apel, pepaya, dan sebagainya. Buah-buahan berfungsi untuk menyuplai vitamin. 
Pada trimester kedua, peran hormon kehamilan yang membuat kondisi ibu tidak karuan sudah tergantikan oleh plasenta sehingga ibu tidak lagi mual dan muntah. Bahkan nafsu makannya sudah berkembang mengikuti kebutuhan gizi ibu yang terus bertambah. Apalagi pertumbuhan janin yang makn pesat juga membutuhkan asupan nutrisi yang besar. Inilah saat yang tepat untuk mengejar ketinggalan gizi pada trimester pertama. Aturlah pola makan ibu, sehingga gizi yang dibutuhkan akan tercukupi.

Berdasarkan hasil penelitian didapatkan hasil mengenai jenis-jenis makanan yang dikonsumsi ibu hamil terutama untuk memenuhan energi dari karbohidrat danprotein. Dari hasil wawancara dengan informan didapatkan hasil bahwa, pengetahuan kebiasaan Makan Menjadi Salah Satu Penyebab seluruh informan mengenai jenis makanan bersumber energi dan proteinyang sudah cukup baik. Seluruh informan dapat menjelaskan dengan benar jenis makanan bersumber energi dan protein. Berikut adalah kutipannya:

"Sumber energi macam roti, nasi, kalau bukanubi atau singkong. Kalau sumberprotein telur, ikan" (Informan o).

plasenta sehingga ibu tidak lagi mual dan muntah. Bahkan nafsu makannya sudah berkembang mengikuti kebutuhan gizi ibu yang terus bertambah. Apalagi pertumbuhan janin yang makn pesat juga membutuhkan asupan nutrisi yang besar. Inilah saat yang tepat untuk mengejar ketinggalan gizi pada trimester pertama. Aturlah pola makan ibu, sehingga gizi yang dibutuhkan akan tercukupi.

Berdasarkan hasil penelitian didapatkan hasil mengenai jenis-jenis makanan yang dikonsumsi ibu hamil terutama untuk memenuhan energi dari karbohidrat danprotein. Dari hasil wawancara dengan informan didapatkan hasil bahwa, pengetahuan kebiasaan Makan Menjadi Salah Satu Penyebab seluruh informan mengenai jenis makanan bersumber energi dan proteinyang sudah cukup baik. Seluruh informan dapat menjelaskan dengan benar jenis makanan bersumber energi dan protein. Berikut adalah kutipannya:

"Sumber energi macam roti, nasi, kalau bukanubi atau singkong. Kalau sumber protein telur, ikan" (Informan o).

"Kalau ikan mengandung protein, kalau sumber energi kaya nasi". (Informan F)

"Ibu hamil bagusnya tempe, telur untuk proteinnya. Kalau energinya dari daging-dagingan sama susu"(Informan S).

\section{Frekuensi dan Porsi Makanan}

Status gizi ibu hamil mempunyai dampak langsung pada perjalanan kehamilan dan bayi yang akan dilahirkannnya. Malnutrisi yang terjadi pada bulan awal kehamilan mempengaruhi perkembangan dan kapasitas embrio untuk bertahan hidup, nutrisi yang buruk pada masa lanjut kehamilan mempengaruhi pertumbuhan janin (Afni, 2014).

Makanan ibu hamil mempunyai peranan penting bagi tumbuh kembang janin dan pada saat ibu melahirkan. Selama kehamilan seorang ibu akan mengalami perubahan baik anatomis, fisiologis, maupun perubahan lainnya yang akan meningkatkan kebutuhan zat gizi dalam makanannya. Di dalam rahim ibu terdapat janin yang sedang tumbuh, ditempat lain beberapa organ tubuh ibu mengalami perubahan fungsi dalam rangka mempersiapkan kehadiran sang bayi (Afni, 2014).

Banyaknya makanan yang dibutuhkan oleh ibu hamil tergantung dari kondisi badan si ibu. Namun jika terjadi gangguan masa kehamilan maka dapat diatur sebagai berikut :

1. Pada Trimester I: 
Pada umur kehamilan 1-3 bulan kemungkinan terjadi penurunan berat badan. Hal ini disebabkan adanya gangguan pusing, mual bahkan muntah. Untuk itu dianjurkan porsi makanan kecil tetapi sering. Bentuk makanan kering/tidak berkuah.

2. Pada Trimester II :

Nafsu makan ibu membaik, makan makanan yang diberikan : 3x sehari ditambah $1 \mathrm{x}$ makanan selingan. Hidangan lauk pauk hewani seperti : telur, daging, teri, hati sangat baik dan bermanfaat untuk menghindari kurang darah .

\section{Pada Trimester III :}

Makanan harus disesuaikan dengan keadaan badan ibu. Bila ibu hamil mempunyai berat kelebihan, maka makanan pokok dan tepung-tepungan dikurangi, dan memperbanyak sayur-sayuran dan fungsi dalam rangka mempersiapkan kehadiran sang bayi (Afni, 2014).

Pada bagian ini yang dibahas adalah frekuensi dan porsi makanan ibu hamil yang dikaji dari aspek pembentuk perilaku. Aspek yang dapat dilihat adalah pengetahuan seputar frekuensi dan porsiyang baik dan sikap serta ada tidaknya kepercayaan terhadap frekuensi dan porsimakan tersebut. Pengetahuan mengenai frekuensi dan porsi yang baik bagi ibuhamil tidak hanya ditanyakan pada informan utama tapi juga pada informan pendukung. $\mathrm{Hal}$ ini dilakukan agar data yang didapatdari informan utama dapat disbanding kandengan data yang diperoleh dari informan pendukung. Oleh sebab itu digunakan triangulasi sumber dalam penelitian ini, yang artinya menggunakan lebih dari satusumber dalam hal ini adalah informan. Dari hasil wawancara diperoleh gambaran frekuensi dan porsi kudapan yang cukup baik pada informan $S$, namun porsi makanan utamanya kurang baik. Hal inisesuai dengan pendapat Suhardjo, (1989). Berikut kutipannya:

"Nasinya tidak terlalu banyaklah palingbanyak 2 leper, harus ada sayur sama lauk-lauk inti, harus kalo buah saya tidak terlalusuka buah"(Informan S).

\section{Kepercayaan Dan Pantangan Terhadap Makanan}

Pantang makan adalah anjuran yang tidak diperbolehkan dan biasanya berkaitan dengan proses pemulihan kondisi fisik misalnya, ada makanan tertentu yang sebaiknya dikonsumsi untuk memelihara kesehatan. Ada pula makanan tertentu yang dilarang karena dianggap dapat mempengaruhi kesehatan ibu dan janin. Pantang atau tabu adalah suatu larangan untuk mengkonsumsi jenis makanan tertentu karena terdapat ancaman bahaya terhadap barang siapa yang melanggarnya. Dalam ancaman bahaya ini terdapat kesan magis, yaitu adanya kekuatan superpower yang berbau mistik yang akan menghukum orang-orang yang melanggar pantangan tersebut. Pada kenyataannya hukuman ini tidak selalu terjadi. Pantangan merupakan sesuatu yang diwariskan dari leluhur melalui orangtua, terus ke generasi-generasi di bawahnya. Hal ini menyebabkan orang tidak tau lagi kapan suatu pantangan atau tabu makanan dimulai dan apa sebabnya. Seringkali nilai sosial ini tidak sesuai dengan nilai gizi makanan.

Pantangan makanan adalah bahan masakan dan makanan yang tidak boleh dimakan oleh para individu dalam masyarakat karena alasan yang bersifat budaya. Adat menantang yang diajarkan secara turun temurun dan cenderung ditaati walaupun individu yang ditaati tidak terlalu faham atau yakin dari alasan melakukan pantang makanan, jenis pantangan (Mahendra, 2014).

Berikut akan dijelaskan mengenai kepercayaan mengenai pantangan / larangan untuk makan makanan tertentu. Dari hasil wawancara mendalam dengan informan utama, seluruh informan memiliki pantangan atau larangan terhadap makanantertentu. Makanan yang menjadi pantangan bagi mereka adalah makanan yang tidak baik dimakan oleh ibu hamil. Selain itu mereka juga mengenal makanan yang baik dimakanoleh ibu hamil. Berdasarkan 
hasil wawancara dengan informan utama didapatkan makananpantangan bagi ibu tersebut yaitu seperti buah nenas, makanan berkaleng, telur, bakso, makanan pedas, minuman bersoda, dankopi. Dari hasil wawancara dengan informan utama, informan $\mathrm{M}$ dan $\mathrm{S}$ tidak memilih makanan tertentu yang memang baik untuk dipantang bagi ibu hamil.

Di satu sisi, ada informan yang memilih makanan tertentu untuk dipantang padahal makanan tersebut baik untuk dikonsumsi bagi ibu hamil. Makanan tersebut diyakini mengandung protein tinggi yang baik untuk gizi ibu hamil. (Almatsier, 2004).

\section{Cara Pemilihan Makanan}

Makanan ibu hamil harus sesuai dengan kebutuhan yaitu makanan yang seimbang dengan perkembangan masa kehamilan. Ibu hamil sebaiknya menerapkan menu empat sehat lima sempurna. Triwulan I, pertumbuhan ja sehingga kebutuhan gizi untuk pertumbuhan janin belum begitu besar, tetapi pada masa ini sering terjadi masalah-masalah "ngidam" dan muntah, karena itu kebutuhan gizi harus diperhatikan. Triwulan II dan III, pada masa ini pertumbuhan janin berlangsung lebih cepat dan perlu diperhatikan kebutuhan gizinya. Kebutuhan kalori ibu hamil ditambah 300 kalori sehingga menjadi sekitar 2500 Kkal (Gunawan, 2013).

Kebutuhan gizi pada masa kehamilan berbeda dengan masa sebelum hamil, peningkatan kebutuhan gizi hamil sebesar $15 \%$, karena dibutuhkan untuk pertumbuhan rahim, payudara, volume darah, plasenta, air ketuban dan pertumbuhan janin. Makanan yang dikonsumsi ibu hamil dipergunakan untuk pertumbuhan janin sebesar $40 \%$, sedangkan yang $60 \%$ untuk memenuhi kebutuhan ibu. Apabila masukan gizi pada ibu hamil tidak sesuai dengan kebutuhan maka kemungkinan terjadi gangguan dalam kehamilan, baik terhadap ibu maupun janin yang dikandungnya (Gunawan, 2013).

Bagian ini akan menjelaskan mengenai cara pemilihan makanan ibu hamil. Aspek pengetahuan yang dilihat adalah pengetahuan ibu hamil dalam memilih bahan makanan dan pengetahuan ibu hamil seputar jenis makanan yang bergizi bagi ibu hamil. Berdasarkan hasil wawancara dengan informan utama, masing-masing informan memilki pengetahuan yang berbeda mengenai cara memilih bahan makanan. Ada informan yang sudah mengerti danpaham tetapi ada juga informan yang belum paham bagaimana memilih bahan makananyang baik. Berikut adalah kutipannya:

“intinya makan nasi ada sayur dengan buah"(Informan S).

\section{Kesimpulan}

Ibu hamil masih banyak yang tidak menerapkan kebiasaan makan bersama keluarga, pola makanan ibu hamil yang kurang beragam, porsi makanan utama ibu hamil masih kurang adekuat. Masih ada pantangan terhadap makanan bersumberenergi dan protein tinggi seperti ikan, telur dan nenas, distribusi makanan keluarga yang kurang tepat. Cara pemilihan makanan yang kurang baik menjadi salah satu penyebab terjadinya kekurangan energi kronis padaibu hamil di Wilyah Kerja Puskesmas Pulubala.

\section{Saran}

a. Petugas kesehatan diharapkan dapat memberikan Komunikasi, Informasi, Edukasi (KIE) tentang kebiasaan makan yang baik kepada ibu hamil, suami dan ibukandung dari ibu hamil agar ibu hamil memiliki bekal pengetahuan gizi yang baik sehingga terhindar dari kekurangan zat gizi terutama KEK.

b. Penyuluhan khusus terkait masalah kebiasaan makan yang baik untuk ibu hamil perlu diadakan di puskesmas tersebut. Puskesmas juga dapat mengadakan pelatihan 
keterampilan khusus seperti memasak makanan yang bergizi dimulai dari cara pemilihan bahan makanan, penyiapan, pengolahan, penyajian, dan distribusi makanan tersebut untuk keluarga.

\section{DAFTAR PUSTAKA}

Muhamad Zuriati, Sumarmi Sri, 2018. Factors Affecting the Incidence of Chronic Energy Deficiency among pregnant Women attending the Pulubala Community Health Centre. Indian Journal of Public Health Research and Development, November 2018, Vol.9 no.11.

Muhamad Zuriati, Liputo Salahudin 2017. Peran Kebijakan Pemerintah Daerah Dalam Menanggulangi Kekurangan Energi Kronik di Kabupaten Gorontalo. Promotif : Jurnal Kesehatan Masyarakat Vol.7 No.2 Desember 2017.

Muhamad Zuriati, Sumarmi Sri, 2018. Factors Affecting the Incidence of Chronic Energy Deficiency among pregnant Women attending the Pulubala Community Health Centre. Indian Journal of Public Health Research and Development, November 2018, Vol.9 no.11.

Muhamad Zuriati, Sumarmi Sri, 2018. The Relationship between Knowledge and Family Income of Chronic Energy Deficiency on Pregnancy in Buhu Health Centre. Prosiding Asia-Pasific Academic Consortium for Public Health Confrence Kinabalu-Sabah.

Kartikasari, 2011. Pola Makan dan Konsumsi Tablet Besi Pada Ibu Hamil Trimester Ketiga di Wilayah Kerja Puskesmas Lubuk Sikaping. Skripsi, Universitas Sumatera Utara, Medan.

Amlatsier, 2004. Hubungan Pola Konsumsi, Ketersediaan Pangan, Pengetahuan Gizi Dan Status Kesehatan Dengan Kejadian KEK Pada Ibu Hamil Di Kabupaten Simalungun. Tesis, Universitas Sumatera Utara, Medan.

Dinas Kesehatan Gorontalo, 2016. Data Ibu Hamil 2016. Gorontalo.

Emilia, 2012. Gizi \& Kesehatan Reproduksi. Cakrawala IImu. Yogyakarta.

Gunawan, 2013. Pengetahuan Gizi Ibu Hamil Trimester Pertama Dan Pola Makan Dalam Pemenuhan Gizi Di Wilayah Kerja Puskesmas Parsoburan Kabupaten Toba Samosir. Thesis, Universitas Sumatera Utara, Medan

Mawaddah dan Hardiansyah (2008). Pengaruh Pola Makan Dan Status Gizi Terhadap Kejadian Hypertensi Pada Ibu Hamil Di RSU Tanjung Pura Kabupaten Langkat. Tesis, Universitas Sumatera Utara, Medan.

Mahendra, 2014. Hubungan Pola Makan Ibu Selama Hamil Dengan Berat Badan Lahir Dan Panjang Badan Lahir Bayi Pada Golongan Keluarga Miskin Di Kecamatan Percut Sei Tuan. Skripsi, Universitas Sumatera Utara, Medan.

Waryana, 2010. Kebiasaan Makan Menjadi Salah Satu Penyebab Kekurangan Energi Kronis (Kek) Pada Ibu Hamil Di Poli Kebidanan Rsi \& A Lestari Cirendeu Tangerang Selatan. 